\title{
Concretes with Red Mud Coarse Aggregates
}

\author{
Dênio Ramam Carvalho de Oliveira*, Carlos Rodrigo Costa Rossi
}

\author{
Faculty of Civil Engineering, Federal University of Pará - UFPA, \\ Rua Augusto Correa, 1, CEP 66075-970, Belém, PA, Brazil
}

Received: August 26, 2011; Revised: January 31, 2012

\begin{abstract}
Red mud (RM) is a mineral waste, residue of the Bayer process used to obtain alumina from bauxite. While the exploration of rolled pebble damages the environment and is much more controlled by the government, the huge RM disposal areas do not stop increasing and polluting soil, rivers and groundwater sources in Amazon. In this work, the material mixtures used to produce coarse aggregates presented up to $80 \%$ of RM, $30 \%$ of metakaolin and $30 \%$ of active silica as recycled waste. Several tests were carried out to determine the aggregates physical properties and to evaluate the mechanical performance of the concretes with the new aggregates, including hydraulic abrasion strength, and the results were compared to the reference ones, i.e. rolled pebble concretes. Additionally, the sintering process neutralizes any toxic substance as occur in some RM products like tiles and bricks, and these results have encouraged an industrial or semi-industrial production of RM aggregates for concretes.
\end{abstract}

Keywords: concrete, red mud, coarse aggregate, hydraulic abrasion

\section{Introduction}

The degradation of the natural resources causing a shortage of raw materials supports the search for alternative materials, clean sustainability and waste recycling techniques. Thus, efforts must be done not only for recycling but also for the development of large-scale production materials in attempting to avoid large amounts of waste, especially mineral waste. Currently, Brazil is the third largest world producer of alumina, generating around 6.1 million $t$ of the industrial waste RM per year causing serious damage to the nature. The waste red mud is a byproduct from the aluminum industry, concentrated in the north region of that country, mainly in the Para state, northeast of the Amazon forest. Environmental problems from the inappropriate disposal of waste varies from contamination of rivers, groundwater, soil, flora and fauna damage, corrosion of metal equipment and the bad aspect of the storage areas. Thus, many researches for RM application in constructions have been conducted for both the appropriate allocation of the residue or its use in industrial scale, e.g. Yang $\& \mathrm{Xiao}^{1}$ and Sglavo et al. ${ }^{2}$. Even for a correctly planned factory costs with transport up to the disposal areas associated to the annual huge amounts of RM, without considering costs with installation and maintenance of geosynthetics and contention walls, become its management extremely necessary to enable a better control of the disposed volumes. Therefore, this work presents an innovative alternative application for RM, mixing it with fine sand, metakaolin or active silica for further burning to obtain a ceramic aggregate with mechanical strength and average apparent density appropriate for the application in conventional concretes. However, as it is a case of new material, it is necessary to evaluate the aggregates with physical characterization tests.

*e-mail: denio@ufpa.br
All samples were grouped to enable comparisons in terms of density, unit mass, shape, texture and water absorption in relation to the concretes with natural rolled pebble $\left(\mathrm{SiO}_{2}\right)$ once it is the main coarse aggregate applied in the north region of Brazil, in the Amazon forest. This aggregate come from the Amazon rivers bed and its exploration damages the environment permanently, changes the rivers profile and prejudices the subsistence (fishing) of the riverine people.

To prove the feasibility of high levels of RM in the production of coarse aggregates for concretes, the methodology recommended by Albuquerque ${ }^{3}$ was followed, which achieved satisfactory results with the tested mixtures, good enough to technically compete with the rolled pebble aggregates. On the toxicity of the new aggregates, the vitreous silica structure forms the basis of the compositions for the trading glass, whose properties are modified by the addition of other metal oxides. The wide use of silica in the ceramic is due to its hardness, infusibility, low cost and ability to form glasses. If in the manufacturing process, during the formation of glassy phase, the gases escape, no swelling of clay particles is possible, these defects can be corrected by adding appropriate fusible materials, as the burned oil, which lifts the period of gas releasing to higher temperatures, or by faster heating with less introduction of air or by adding substances that increase the viscosity of the glassy phase. This vitreous structure becomes the RM aggregates inert and secure to be handed ${ }^{4,5}$. The mechanical properties of the concrete mixtures of Albuquerque ${ }^{3}$ were also competitive, with an average compressive strength of $20 \mathrm{MPa}$ and an average elasticity modulus of $26 \mathrm{GPa}$, equaling and surpassing in $26 \%$ the values found for the reference concrete (with rolled pebble), respectively. Then, trying to improve the performance of the new aggregates 
mixtures with proportions of $1: 1.5: 2.5$ or $1: 1.5: 3.0$ in mass were tested. The results overcame expectations for all tests, corroborating the use of the new alternative materials involved by hard concrete.

\section{Experimental Program}

\subsection{Materials}

\subsubsection{Red mud}

The residue used in this work came from a mining company placed near to Belém city, in the north region of Brazil. Generically, this RM has a typical composition and is an insoluble residue generated during the clarification stage of the Bayer process in the alumina production. The chemical composition of RM can be variable and depends on the nature of the bauxite. Normally, the RM retains all iron, titanium and silica present in the bauxite, besides the aluminum not extracted during the refining, combined with sodium in the form of an aluminum silicate hydrated and sodium of zeolitic nature. The most common mineral phases are hematite $\left(\alpha-\mathrm{Fe}_{2} \mathrm{O}_{3}\right)$, goethite $(\alpha-\mathrm{FeOOH})$, magnetite $\left(\mathrm{Fe}_{3} \mathrm{O}_{4}\right)$, boehmite $(\gamma-\mathrm{AlOOH})$, quartz $\left(\mathrm{SiO}_{2}\right)$, sodalite $\left(\mathrm{Na}_{4} \mathrm{Al}_{3} \mathrm{Si}_{3} \mathrm{O}_{12} \mathrm{Cl}\right)$ and gypsum $\left(\mathrm{CaSO}_{4} \cdot 2 \mathrm{H}_{2} \mathrm{O}\right)$, with small amounts of calcite $\left(\mathrm{CaCO}_{3}\right)$ and gibbsite $\left(\mathrm{Al}(\mathrm{OH})_{3}\right)$, according to Barrand \& Gadeau ${ }^{6}$ and Motta \& Oliveira ${ }^{7}$. Table 1 presents the chemical composition of the RM used as raw material to produce coarse aggregates, and Figure 1 shows the X-ray diffraction ${ }^{8}$.

On the toxicity of the waste, the Environmental Protection Agency (EPA) does not classify the RM as a hazardous waste. However, there is a presence of high levels of calcium and sodium hydroxide, leaving the RM toxic and constituting a danger to people nearby. One of the reasons for the environmental impacts caused by the high alkalinity is due to the same elements that make it toxic (Soda). The large world production of RM is associated with a more rigorous implementation of ecological monitoring. Several countries have adopted appropriate procedures to dispose of this waste in a correct way to avoid the contamination of the soil and rivers, as shown on Figure 2. In China, around $10 \%$ of $\mathrm{RM}$ produced is recycled for extraction of metal or used as raw material for bricks production. The ceramic blocks were used in constructions at the southeast of Australia. A whole house with RM ceramic products was built in Barcarena, a small city placed $200 \mathrm{~km}$ from Belém, where tests are being carried out to verify the possibility of incorporation of this waste in the Portland cement. The amount of RM disposed in Amazon represents 80\% of the Brazilian annual production, 6.132 million $\mathrm{t}^{9}$, as shown on Figure 3, and this volume could be totally used to produce bricks and tiles.

\subsubsection{Coarse aggregates}

Aggregate is an inert component that when added to concrete performs the function of filling and resistant material consisting of particles jointed by the cement paste, result from the hydration of the mixture. In this work sand of quartz origin was added as fine aggregate and the rolled pebble was used as reference natural coarse aggregate. Such reference aggregates were sieved according to NBR $7217^{10}$ to present average diameter of $19.0 \mathrm{~mm}$, similar to the average diameter of the aggregates with RM, except RMMC70.

After analyzing the costs generated to produce RM bricks and tiles to build the house in Barcarena, it was verified that the production of aggregates for concretes could be feasible and would consume a large amount of RM as the bricks manufacturing had done. Then, the RM was taken to a drying oven at $100{ }^{\circ} \mathrm{C}$ for 24 hours and after was milled in a mill balls until the large grains become powder, which lasted 2 hours approximately. The mass percentages for each material of the mixtures were 70 or $80 \%$ of RM, 30 or $20 \%$ of fine sand, $2 \%$ of burned oil and $30 \%$ of water, to improve the workability of the composite. Table 2 shows the

Table 1. Chemical composition of the Amazon RM (Hildebrando et al. ${ }^{8}$ ).

\begin{tabular}{cccccccccc}
\hline Composition & $\mathrm{Fe}_{2} \mathbf{O}_{3}$ & $\mathbf{S i O}_{2}$ & $\mathbf{A l}_{2} \mathbf{O}_{3}$ & $\mathbf{N a}_{2} \mathbf{O}$ & $\mathrm{TiO}_{2}$ & $\mathbf{C a O}$ & $\mathbf{K}_{2} \mathbf{O}$ & $\mathbf{M g O}$ & Fire loss \\
\hline$\%$ & 39.2 & 19.18 & 19.10 & 9.01 & 3.04 & 1.21 & 0.10 & 0.04 & 9.12 \\
\hline
\end{tabular}

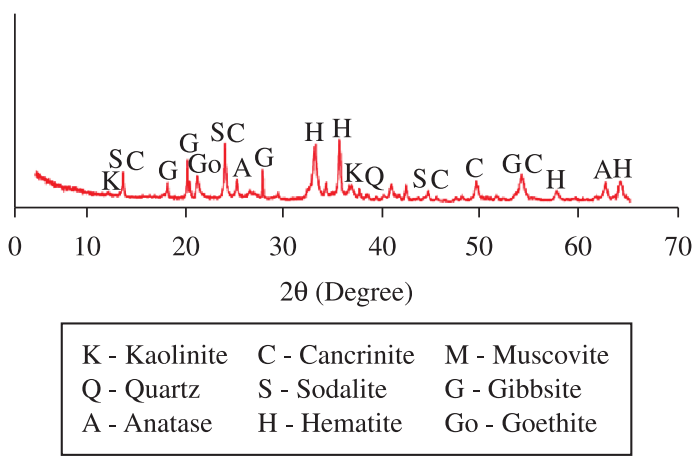

Figure 1. X-ray diffraction of the Amazon red mud (Hildebrando et al. ${ }^{8}$ )

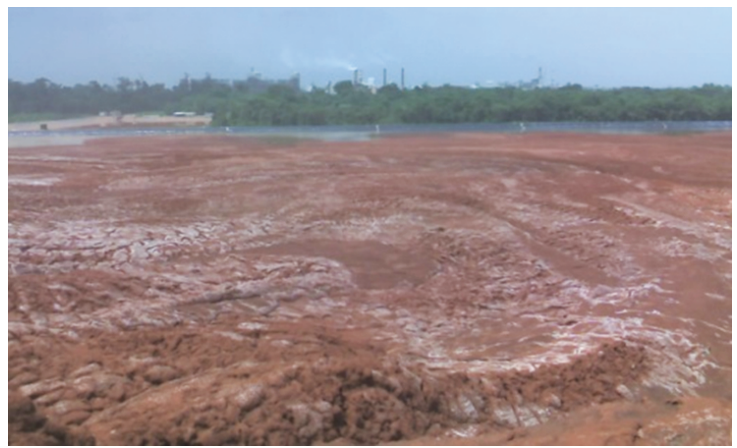

Figure 2. RM disposal area in Pará. 
Table 2. Mixture proportions to produce the RM coarse aggregates.

\begin{tabular}{lccccc}
\hline Mixture & \multicolumn{5}{c}{ Component (\%) } \\
\cline { 2 - 6 } & $\begin{array}{c}\text { Active } \\
\text { silica }\end{array}$ & Metakaolin & $\begin{array}{c}\text { Fine } \\
\text { sand }\end{array}$ & $\begin{array}{c}\text { Thick } \\
\text { sand }\end{array}$ & $\begin{array}{c}\text { Red } \\
\text { mud }\end{array}$ \\
\hline RMAS70 & 30 & 0 & 0 & 0 & 70 \\
RMMC70 & 0 & 30 & 0 & 0 & 70 \\
RMFS70 & 0 & 0 & 30 & 0 & 70 \\
RMTS70 & 0 & 0 & 0 & 30 & 70 \\
RMFS80 & 0 & 0 & 20 & 0 & 80 \\
\hline
\end{tabular}

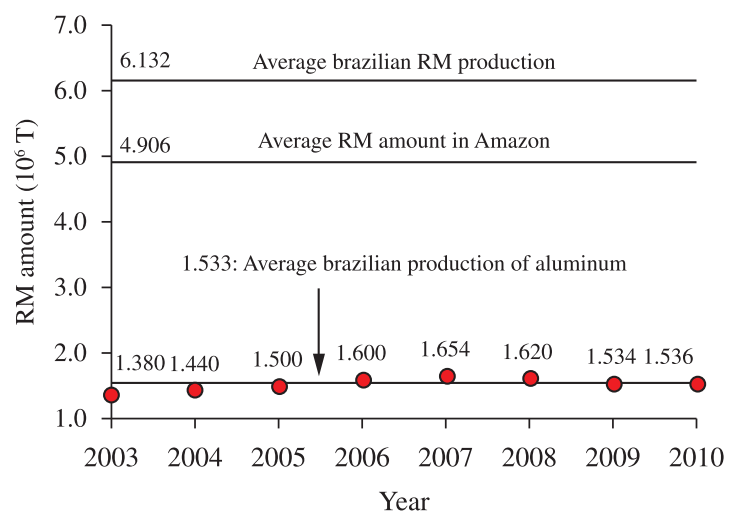

Figure 3. RM amount disposed in Amazon.

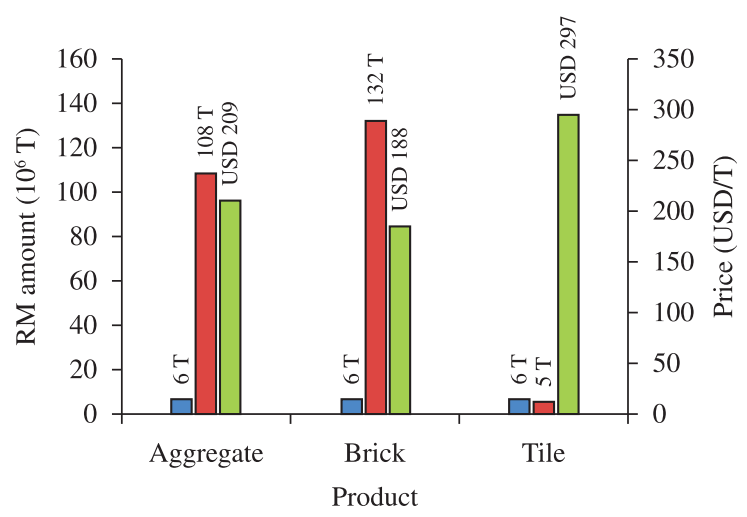

$\square$ RM disposed in Brazil $\square$ RM consumption estimates $\square$ Final price estimates

Figure 4. Consumption of RM and final cost to manufacture aggregates, bricks and tiles based on the Brazilian annual production of these materials.

mixture proportions with fine sand (RMFS70 and RMFS80), thick sand (RMTS70), metakaolin (RMMC70) and active silica (RMA-S70). From these mixtures was possible estimate the costs to produce the referred aggregates in a rotary cylindrical oven taking account the stages applied in the clinker production and its relative costs. It must be remarked that a similar oven was proposed by the researchers of the Federal University of Pará in 2010 to be built by an aluminum producer aiming to produce coarse aggregates

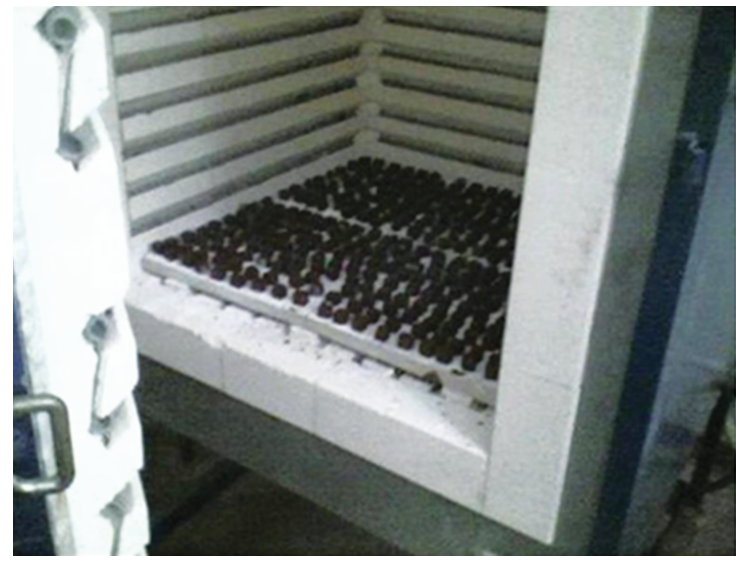

Figure 5. RM coarse aggregates sintering.

for concretes. This proposal is still under analysis. Figure 4 shows a comparison between the estimated consumption and final cost of the RM aggregates, bricks and tiles, and only the tiles annual production did not surpassed the RM annual generation. These final costs are close to those practiced in Brazil, and can be reduced along the manufacturing process of the aggregates.

Cubic metal molds were used for initial conformation of the aggregates, resulting in a well defined cubic geometry with edges of $20 \mathrm{~mm}$, aiming a low variation on the average diameter of the aggregates. After the initial molding the aggregates were still plastic to be rounded manually to simulate the rolled pebble geometry. The next step was to take the aggregates to a special oven (shown on Figure 5), set on a refractory tray covered by alumina powder, and the temperature was increased to $1,200{ }^{\circ} \mathrm{C}$ for sintering for a period of 3 hours approximately. It was found that around $40 \%$ of the final temperature there was a slight shrinkage on the aggregates ranging from 4.8 to $15.0 \%$. Therefore, the maximum diameter was $19.0 \mathrm{~mm}$, except for RMMC70 with $9.5 \mathrm{~mm}$. Figure 6 shows the coarse aggregates ready to be used.

\subsubsection{Concrete mixtures}

The concrete preparation methodology was initially to weight all materials according to the mix proportion of 1:1.5:2.5 in mass. However, after the first tests and aiming better mechanical performance, the ratio coarse aggregate/cement was increased in 20\%, ranging from 2.5 to 3.0 during the dosage of RP19b and RMFS80 samples. The applied materials were the cement CP II-Z-32, washed fine sand and coarse aggregates with RM for comparison with the reference concretes, dosed with rolled pebble. The predicted resistance for the reference concretes was $25 \mathrm{MPa}$, with water/cement (w/c) proportion constant of 0.45 for all mixtures ${ }^{3}$. There was a need of plasticizer additive Glenium 51 in the dosage of the samples RMFS 80 and RP19b, and the amount was in accordance with the recommendation of the manufacturer. Figure 7 shows the mixture procedure and the cylindrical specimen preparation. 


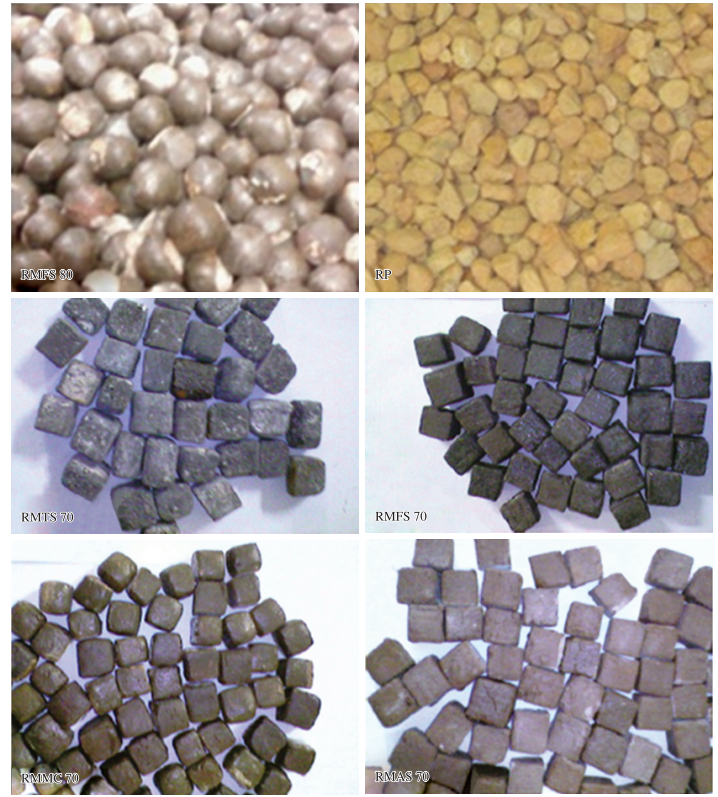

Figure 6. Rolled pebble and RM coarse aggregates ready to be used.

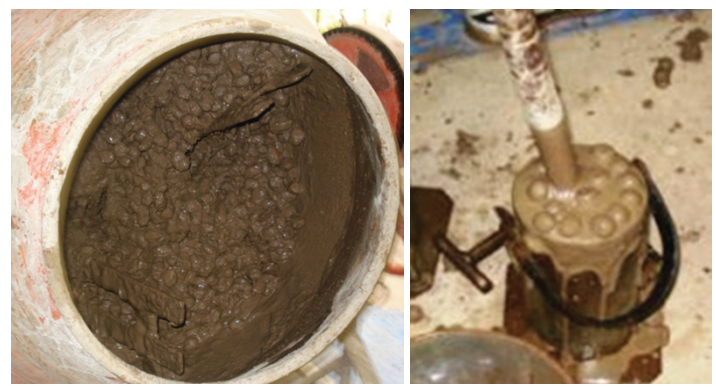

Figure 7. Concrete specimens preparation.

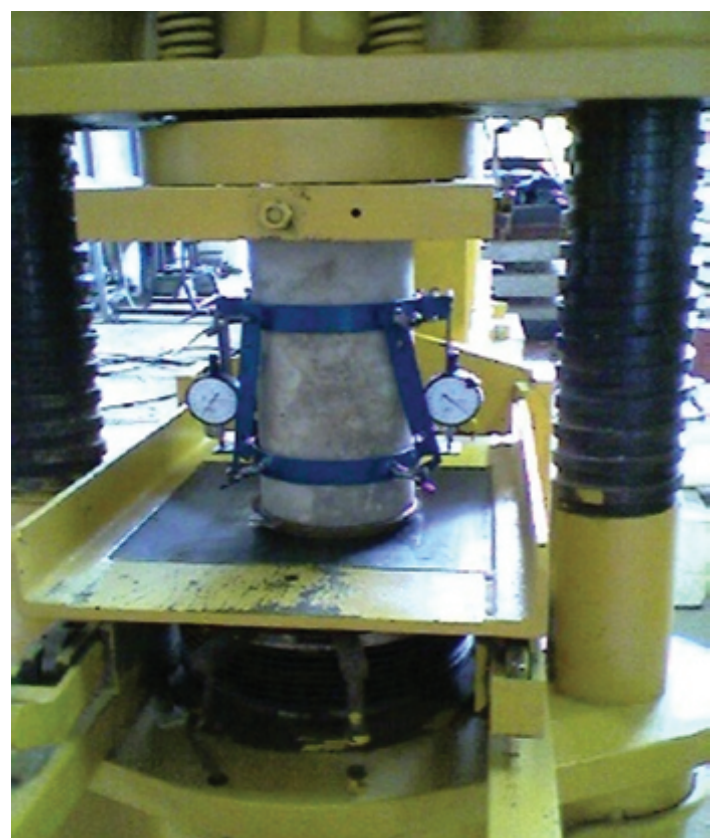

Figure 8. Hydraulic abrasion test.

\subsection{Testing methodology}

\subsubsection{Coarse aggregates}

The RM aggregates physical characteristics as unit mass, density and water absorption were experimentally determined in accordance with the codes NBR $9937^{11}$, NBR $9776^{12}$ and NBR $7251^{13}$, respectively. Only one sample of each aggregate was tested.

\subsubsection{Concrete}

To establish the influence of aggregates (produced with RM and a second raw material) in the physical and mechanical properties of the concretes, several tests were carried out to determine the density, axial compressive resistance and the elasticity modulus. In all cases cylindrical specimens (SPs) were used and grouped as follows: 36 SPs for density tests, 30 SPs for elasticity modulus tests and more 42 SPs for axial compression tests, all proofs with $100 \mathrm{~mm}$ of diameter and $200 \mathrm{~mm}$ of height, totalizing 108 SPs. The testing methodology used to determine the mechanical properties followed the prescriptions of NBR $5739^{14}$, NBR $8522^{15}$ and NBR $7222^{16}$. All specimens were kept under the same environmental conditions in a humid chamber.

The abrasion resistance at 28 days is a very importance parameter because it is the final resistance of the concrete to be considered in the design of weirs, canals and wet concrete pipes lines, which are constructions largely applied in Amazon. Because of this, the resistance at this age is a standard parameter for the performance of these materials over their service life. The testing methodology recommended by ASTM C $1138 \mathrm{M}^{17}$ qualitatively intends to simulate the behavior of water in spiral motion containing suspended solids, i.e. small steel spheres to abrade the concrete, enabling evaluation the relative resistance of the

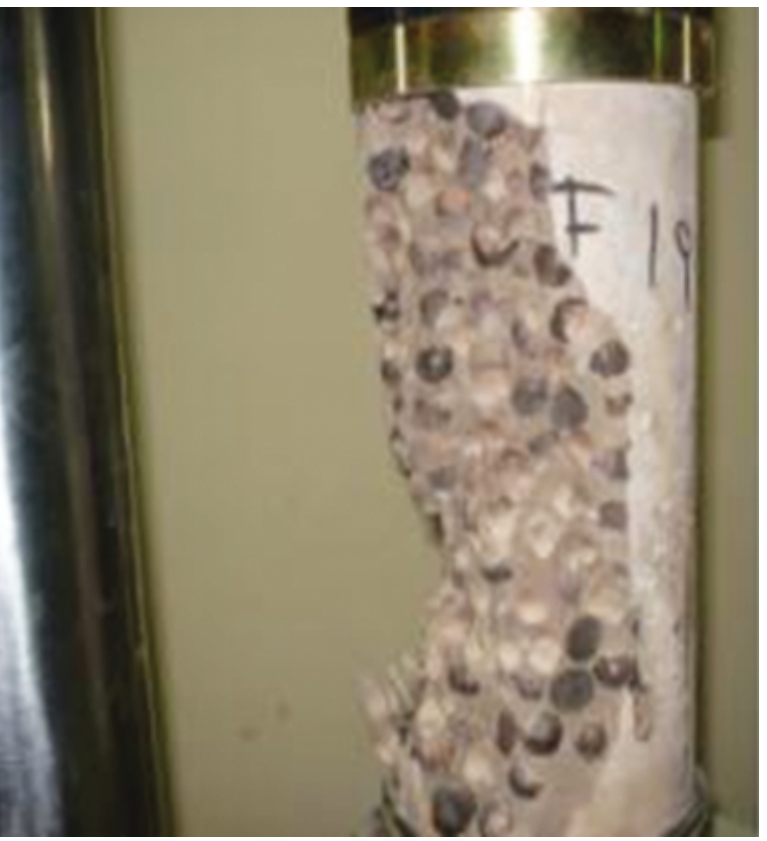


Table 3. Physical properties of the coarse aggregates.

\begin{tabular}{cccccc}
\hline Specimen & $\begin{array}{c}\text { Density } \\
\left(\mathbf{k g . m}^{-3}\right)\end{array}$ & $\begin{array}{c}\text { Unit mass } \\
\left(\mathbf{k g . m}^{-3}\right)\end{array}$ & $\begin{array}{c}\text { Water absorption } \\
(\mathbf{\%})\end{array}$ & $\begin{array}{c}\text { Initial diameter } \\
(\mathbf{m m})\end{array}$ & $\begin{array}{c}\text { Final diameter } \\
(\mathbf{m m})\end{array}$ \\
\hline RP19 & 2,650 & 1,450 & 1,00 & 19.0 & 19.0 \\
RP9.5 & 2,660 & 1,510 & 1,00 & 9.5 & 9.5 \\
RMFS80 & 2,440 & 1,410 & 0.83 & 20.0 & 19.0 \\
RMFS70 & 2,650 & 1,670 & 0.50 & 20.0 & 19.0 \\
RMTS70 & 2,160 & 1,240 & 1.00 & 20.0 & 19.0 \\
RMAS70 & 1,200 & 0,690 & 3.25 & 20.0 & 19.0 \\
RMMC70 & 2,040 & 1,180 & 0.0 & 10.0 & 9.5 \\
\hline
\end{tabular}

Table 4. Concretes' density and mechanical properties.

\begin{tabular}{|c|c|c|c|c|c|c|c|c|}
\hline Concrete sample & RP19a & RP19b & RP9.5 & RMFS80 & RMFS70 & RMTS70 & RMMC70 & RMAS70 \\
\hline Density $\left(\mathrm{kg} \cdot \mathrm{m}^{-3}\right)$ & 2,300 & 2,310 & 2,270 & 2,350 & 2,330 & 2,040 & 2,050 & 1,780 \\
\hline $\mathrm{NSP} / \mathrm{SD}$ & $2 / 1.0$ & $9 / 74.5$ & $3 / 13.2$ & $9 / 64.3$ & $3 / 29.3$ & $3 / 3.8$ & $3 / 7.1$ & $3 / 30.7$ \\
\hline Elasticity modulus (GPa) & 23.6 & 20.6 & 24.3 & 38.9 & 30.2 & 25.8 & 29.9 & 19.4 \\
\hline $\mathrm{NSP} / \mathrm{SD}$ & $3 / 1.5$ & $6 / 1.7$ & $3 / 0.8$ & $6 / 3.5$ & $3 / 1.7$ & $3 / 1.6$ & $3 / 0.5$ & $3 / 1.0$ \\
\hline Compression strength (MPa) & 23.4 & 25.9 & 28.2 & 40.3 & 20.0 & 18.2 & 24.1 & 17.2 \\
\hline NSP/SD & $5 / 2.5$ & $6 / 1.8$ & $5 / 2.8$ & $6 / 2.1$ & $5 / 4.1$ & $5 / 4.3$ & $5 / 2.2$ & $5 / 2.9$ \\
\hline
\end{tabular}

concrete against hydraulic abrasion. Then, six concrete disks with diameter of $300 \mathrm{~mm}$ and height of $100 \mathrm{~mm}$ were prepared, three with RM aggregates and three with rolled pebble. The equipment and testing details are shown on Figure 8.

In this experiment the volumes $\left(\mathrm{V}_{\mathrm{t}}\right)$ of the specimens are determined and then they remain under test for 72 hours and volume measurements are taken each 12 hours, totaling seven measurements (including the zero hour measurement). Thus, the volume is calculated according to Equation 1. The specimen's abrasion is measured in relation to the lost material volume $\left(\mathrm{VL}_{\mathrm{t}}\right)$, taken as the difference between the initial volume of each specimen $\left(\mathrm{V}_{\mathrm{i}}\right)$ and its volume at a given moment $\left(\mathrm{V}_{\mathrm{t}}\right)$, as shown on Equation 2. The results of the tests are the volumes of lost or abraded material for each period of 12 hours. At this time, to compare the samples, the final abrasion test results were used, i.e. results of 72 hours of abrasion. Another way to show the test results, according to ASTM C1138M ${ }^{17}$, is to measure the average abraded height $\left(\mathrm{HE}_{\mathrm{t}}\right)$, considering the area on the top of the specimen (A) always constant, according to Equation 3.

$V_{t}=\frac{W a-W_{W}}{G_{W}}$

$V L_{t}=V_{t}-V_{i}$

$H E_{t}=V L_{t} / A$

With,

- $\mathrm{W}_{\mathrm{a}}$ : mass of the specimen in saturated air;

- $\mathrm{W}_{\mathrm{w}}$ : apparent mass of the specimen;

- $\mathrm{G}_{\mathrm{w}}$ : density of water.

\section{Experimental Results}

\subsection{Aggregates physical characterization}

The lowest value for density was found for RMAS70 which presented the highest water absorption of $3.5 \%$. The highest density was for RMFS70, but with water absorption of $0.5 \%$, as presented in Table 3 . The classification according to the density of aggregates was performed as follows: lightweight aggregates $\left(\gamma<1,120 \mathrm{~kg} \cdot \mathrm{m}^{-3}\right)$, normal weight aggregates $\left(1,120 \mathrm{~kg} \cdot \mathrm{m}^{-3}<\gamma<2,080 \mathrm{~kg} \cdot \mathrm{m}^{-3}\right)$ and heavy aggregates $\left(\gamma>2,080 \mathrm{~kg} \cdot \mathrm{m}^{-3}\right)^{18}$. From the experimental results the RM aggregates were classified as heavy weight, except RMAS70 and RMMC70, classified as normal weight aggregates, with RMAS70 presenting just $1,200 \mathrm{~kg} \cdot \mathrm{m}^{-3}$. This lower value for active silica had already been observed in previous researches and new RM lightweight aggregates are being developed in the Federal University of Pará using additives to increase releasing of gases and become the structure of these aggregates more porous.

\subsection{Concrete physical and mechanical characterization}

All specimens were tested at the age of 28 days and the average results are presented in Table 4 . In this table, NSP and SD mean number of tested specimens and standard deviation, respectively. For all tests of axial compression and elasticity modulus a servo-controlled machine was used. The experimental results are discussed below.

\subsubsection{Density}

The concrete density was obtained through the mass/volume relationship for all 36 SPs. The lowest value was found for the RMAS70 concrete, $1,780 \mathrm{~kg} \cdot \mathrm{m}^{-3}$. It was expected once the lightest aggregate was also RMAS70, 


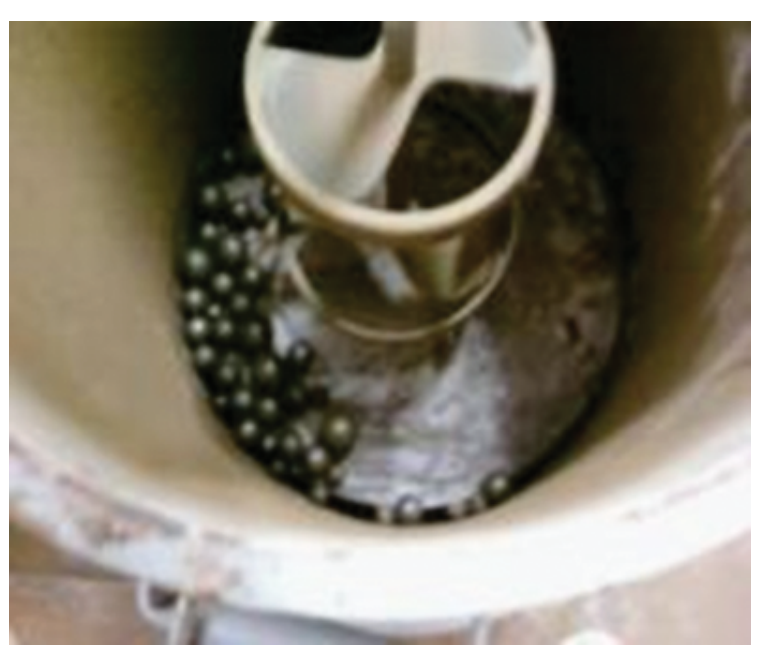

Figure 9. Elasticity modulus and axial compression tests.

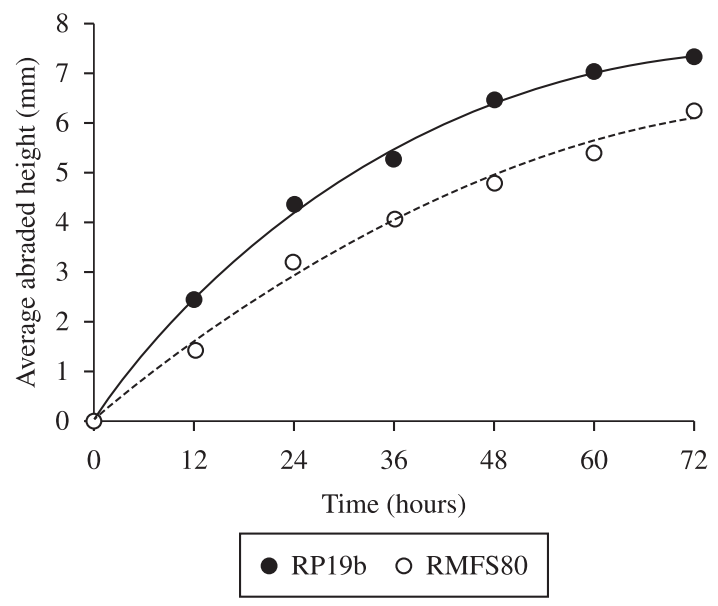

Figure 10. Abrasion evolution through height loss measures.

which reduces the overall hard concrete weight, and as the mass proportion of cement plus fine aggregate to coarse aggregate is 1.0, the final result should be close to an average density. The highest value was found for RMFS80, $2,350 \mathrm{~kg} \cdot \mathrm{m}^{-3}$, just $2 \%$ higher than the reference concrete RP19b.

\subsubsection{Elasticity modulus}

The elasticity modulus tests on the 30 SPs with RM and rolled pebble aggregates at the age of 28 days were conducted in accordance with NBR 8522 $2^{15}$. Except the group RMAS70 all concretes with RM aggregates presented values higher than the reference ones. The highest value of $38.9 \mathrm{GPa}$ was found for RMFS 80 and was $90 \%$ higher than that for RP19b, with same mixture proportion. The elasticity modulus is directly related to the properties of the cement paste, with the modulus of stiffness of the aggregates and the method of its determination. In general, coarse aggregates can represent up to $70 \%$ of the normal concrete volume (compressive strength $<50 \mathrm{MPa}$ ), and

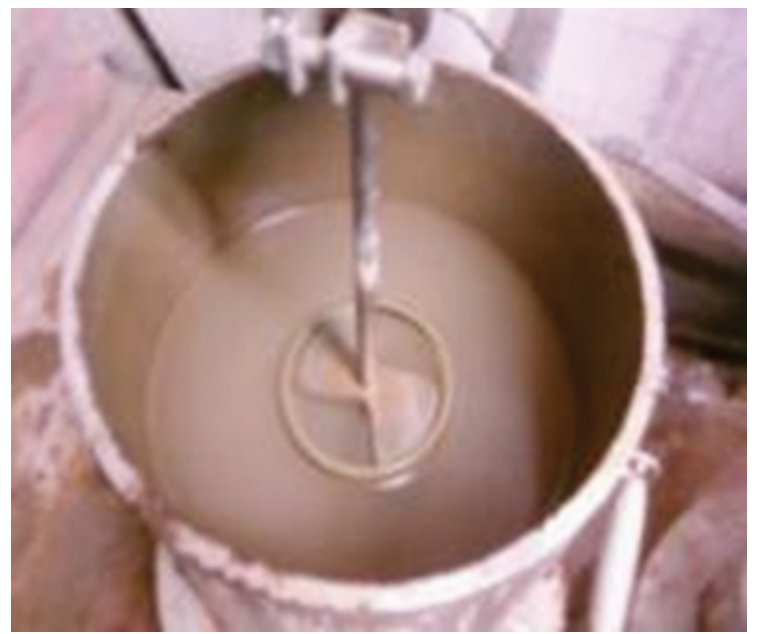

this high percentage enables to suppose that their physical and mechanical properties can influence the mechanical properties of the concretes significantly ${ }^{18}$. In this work the elasticity modulus of the aggregates were not determined, but it was observed that this mechanical property for the concretes with RM aggregates varied with the density of the concretes, and the value found for RMFS80 was twice the value for RMAS70, following the same proportion between their coarse aggregate density, which resulted in a larger amount of RMAS70 aggregate and porosity.

\subsubsection{Axial compression strength}

The average experimental values for axial compression strength of all samples were found according to NBR $5739^{14}$ prescriptions. The reference concrete strengths were close to the expected for 28 days, $25 \mathrm{MPa}$ and the concrete with the aggregate sample RMFS 80 presented resistance around $40 \mathrm{MPa}$, corroborating the elasticity modulus behavior and being $67 \%$ higher than the sample RMMC70. Figure 9 shows the final aspect of the samples where the failure cracks occurred in the paste, indicating the high strength of the material used as aggregate.

\subsubsection{Hydraulic abrasion strength}

The average hydraulic abrasion experimental results are presented in Table 5. Figure 10 shows the average abraded height evolution versus the elapsed time considering specimens RMFS19-80 and RP19b. The average abraded height for RMFS80 was around $85 \%$ of the reference concrete RP19b, but the larger difference found between the disks was $30 \%$, that can be explainable by the greater mechanical resistance of the concrete.

Figure 11 shows the aspect of the disks surface between second (12 hours) and seventh measurement (72 hours) for both concretes. RMFS80 concrete abraded less and presented a uniform aspect and only the RP concrete began to abrade in the aggregate at the time of 12 hours. The RM aggregate abrasion was just recorded in the third measurement ( 24 hours). After the seventh measurements, according to ASTM C1138M ${ }^{17}$, all specimens were dried 
Table 5. Abraded volume and height for RP19b and RMFS80 concrete disks.

\begin{tabular}{|c|c|c|c|c|c|c|c|c|}
\hline \multirow[t]{2}{*}{ Sample } & \multirow[t]{2}{*}{ Parameter } & \multicolumn{7}{|c|}{ Hours } \\
\hline & & $\mathbf{0}$ & 12 & 24 & 36 & 48 & 60 & 72 \\
\hline \multirow[t]{4}{*}{ SR19b } & $\mathrm{VL}_{\mathrm{t}}$ (liter) & 0.000 & 0.173 & 0.308 & 0.372 & 0.457 & 0.495 & 0.517 \\
\hline & NSP/SD & 0.000 & $3 / 0.046$ & $3 / 0.100$ & $3 / 0.070$ & $3 / 0.093$ & $3 / 0.107$ & $3 / 0.122$ \\
\hline & $\mathrm{HE}_{\mathrm{t}}(\mathrm{mm})$ & 0.000 & 2.448 & 4.357 & 5.267 & 6.465 & 7.008 & 7.314 \\
\hline & NSP/SD & 0.000 & $3 / 0.649$ & $3 / 1.412$ & $3 / 0.992$ & $3 / 1.318$ & $3 / 1.515$ & $3 / 1.728$ \\
\hline \multirow[t]{4}{*}{ RMFS80 } & $\mathrm{VL}_{\mathrm{t}}$ (liter) & 0.000 & 0.103 & 0.223 & 0.288 & 0.343 & 0.385 & 0.442 \\
\hline & NSP/SD & 0.000 & $3 / 0.058$ & $3 / 0.072$ & $3 / 0.069$ & $3 / 0.045$ & $3 / 0.010$ & $3 / 0.037$ \\
\hline & $\mathrm{HE}_{\mathrm{t}}(\mathrm{mm})$ & 0.000 & 1.146 & 3.155 & 4.070 & 4.852 & 5.451 & 6.253 \\
\hline & NSP/SD & 0.000 & $3 / 0.818$ & 3/1.013 & $3 / 0.978$ & $3 / 0.633$ & $3 / 0.134$ & $3 / 0.526$ \\
\hline
\end{tabular}
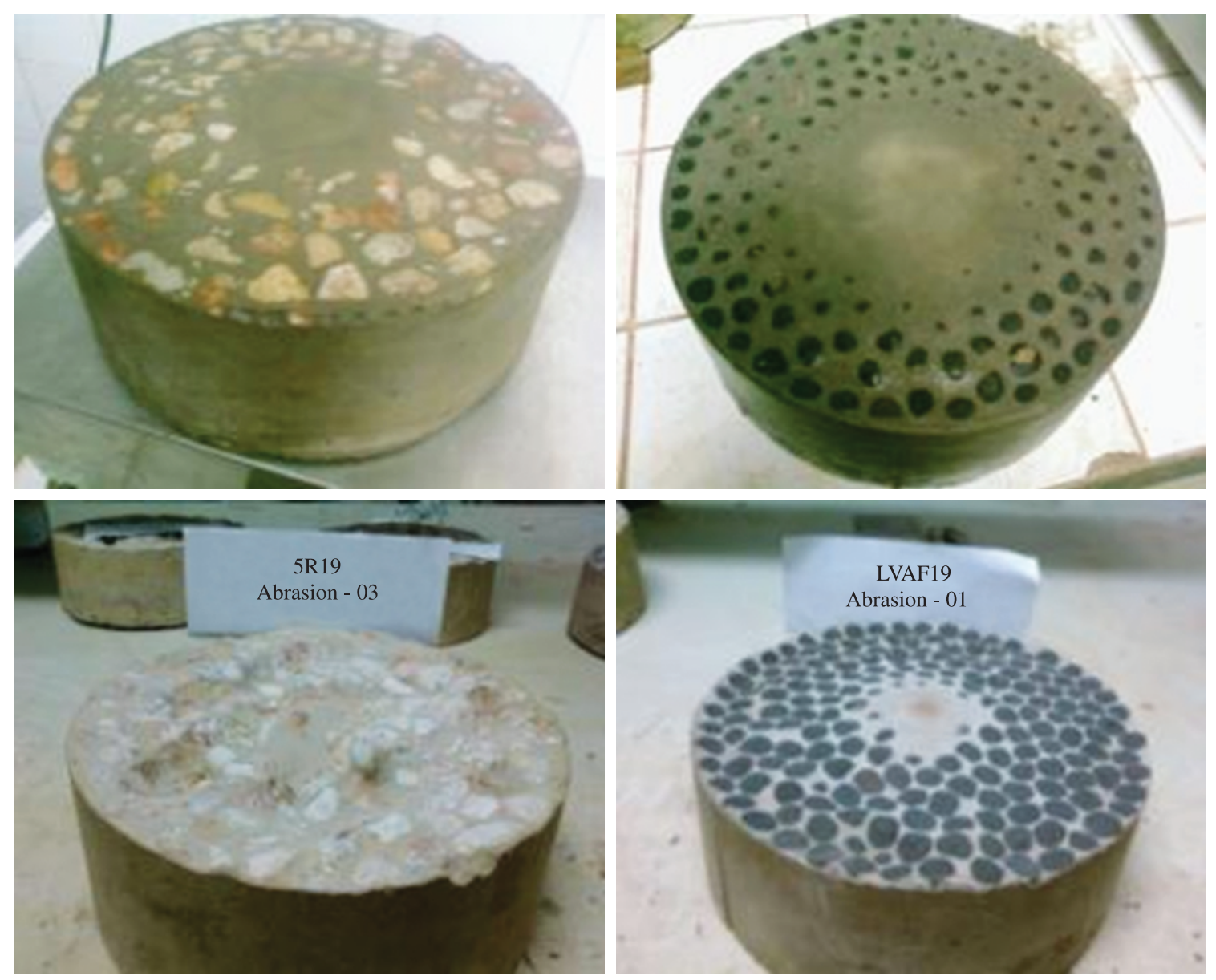

Figure 11. Concrete disks after second and seventh (bottom) abrasion measurements.

up in an oven at $100{ }^{\circ} \mathrm{C}$ during 24 hours and weighed to determine the dry abraded mass. The average lost mass for RMFS19-80 samples was $8.5 \%$ against $9.2 \%$ of the references RP19b.

\section{Conclusion}

The direct use of red mud in the production of different types of new RM coarse aggregates leads to results quite motivating. The average value for axial compression strength of the sample RMFS 80 was $55 \%$ higher than RP19b and $67 \%$ above of RMMC70. The result was more significant for the modulus of elasticity, exceeding the value of RP19b in $89 \%$. Considering the abrasion resistance of the RMFS80 concrete, it was verified a lower abrasion degree. Due to the rounder shape of the new aggregates, with a smaller contact area, and to the stronger cement paste, the RMFS 80 concrete had an average abraded height $15 \%$ lower than the RP19b concrete. It was an expected and reasonable result once normal weight aggregates were used, but the application 
of RM as aggregates for concretes resistant to hydraulic abrasion proved to be technically feasible and indicates its durability under hard conditions. The rounded shape, the highest concentration of waste (RM) in the mixture and, especially, the higher proportion of coarse aggregates contributed to the best mechanical performances. Therefore, despite of the few tests carried out and discussed in this work, and no information concerning the durability of these alternative aggregates, their application in conventional

\section{References}

1. Yang $\mathbf{J}$ and Xiao B. Development of unsintered construction materials from red mud wastes produced in the sintering alumina process. Construction and Building Materials. 2008; 22:22992307. http://dx.doi.org/10.1016/j.conbuildmat.2007.10.005

2. Sglavo VM, Maurina S, Conci A, Salviati A, Carturan G and Cocco G. Bauxite red mud in the ceramic industry. Part 2: production of clay-based ceramics. Journal of the European Ceramic Society. 2000; 20:245-252. http://dx.doi.org/10.1016/ S0955-2219(99)00156-9

3. Albuquerque NGB. Estudo das Propriedades Mecânicas de Concretos Dosados com Agregados de Lama Vermelha. In: Proceedings of the 49th Brazilian Congress on Concrete, 2007; Bento Gonçalves. Bento Gonçalves; 2007. p. 1-11.

4. Vieira TM. Estudo sobre parâmetros de reciclagem da lama vermelha para produção de agregados leves para a indústria da construção civil. [Tese]. Belém: Federal University of Pará; 2006.

5. Antunes MLP, Conceição FT and Navarro GRB. Caracterização da Lama Vermelha Brasileira (Resíduo do Refino da Bauxita) e Avaliação de suas Propriedades para Futuras Aplicações. In: Proceedings of the 3th International Workshop on Advances in Cleaner Production; 2011; São Paulo. São Paulo; 2011. p. 1-10.

6. Barrand P and Gadeau R. Encyclopedia of the Aluminium. Bilbao: Urmo; 1967.

7. Motta M and Oliveira EH. Study on red mud application to remove textile colorings. New Chemistry. 2008; 31:985-989.

8. Hildebrando EA, Souza JAS and Neves RF. Influence of the type of clay over the mechanical and physical properties of ceramic proofs with red mud from the Bayer process. In: Proceedings of the 17th Brazilian Congress on Materials Science and Engineering; 2006; Fox do Iguaçu, Brazil: 17th Brazilian Congress on Materials Science and Engineering Publication; 2006. p. 1574-1583. concretes seems to be possible and satisfactory, but others properties must be investigated to enable an industrial or semi-industrial scale production.

\section{Acknowledgments}

The authors thank to CAPES, CNPq and ITEGAM by the financial support in developing this and other researches in the Amazon forest.
9. Brazilian Aluminum Association - ABAL. A Indústria: Estatísticas. Available from: <http://www.abal.org.br/industria/ estatisticas_alumina.asp $>$. Access in: 15/08/2011.

10. Associaçao Brasileira de Normas Técnicas - ABNT. NBR 7217: Aggregates - Sieve analysis of fine coarse aggregates - Method of test. Rio de Janeiro: ABNT; 1987.

11. Associaçao Brasileira de Normas Técnicas - ABNT. NBR 9937: Agregados - determinação da absorção e da massa específica de agregado graúdo. Rio de Janeiro: ABNT; 1987.

12. Associaçao Brasileira de Normas Técnicas - ABNT. NBR NM 52: agregado miúdo - determinação de massa específica e massa específica aparente. Rio de Janeiro: ABNT; 2003.

13. Associaçao Brasileira de Normas Técnicas - ABNT. NBR $N M$ 45: agregados - determinação da massa unitária e do volume de vazios. Rio de Janeiro: ABNT; 2006.

14. Brazilian Association of Technical Standards. NBR 5739: Concreto - Ensaios de compressão de corpos-de-prova cilíndricos. Rio de Janeiro: ABNT; 2007.

15. Associaçao Brasileira de Normas Técnicas - ABNT. NBR 8522: Concreto -Determinação do Módulo de Deformação Estática e Diagrama. Rio de Janeiro: ABNT; 2008.

16. Associaçao Brasileira de Normas Técnicas - ABNT. NBR 7222: Concreto e argamassa - Determinação da resistência à tração por compreensão diametral de corpos de prova cilíndricos. Rio de Janeiro: Brazilian Association of Technical Standards; 2011.

17. American Society for Testing and Materials - ASTM. ASTM C1138M: Standard Test Method for Abrasion resistance of concrete (underwater method). Philadelphia: ASTM; 2005.

18. Mehta PK and Monteiro PJM. Concrete: structures, properties, and materials. Englewood Cliffs: Prentice Hall; 1993. 